\title{
Resistance to dehydration and positive hygrotaxis in the invasive red swamp crayfish Procambarus clarkii
}

\author{
Silvana Piersanti ${ }^{1}$, Matteo Pallottini ${ }^{1}$, Gianandrea Salerno ${ }^{2}$, Enzo Goretti ${ }^{1}$, Antonia Concetta Elia ${ }^{1, *}$, \\ Ambrosius Josef Martin Dörr ${ }^{1}$ and Manuela Rebora ${ }^{1}$ \\ ${ }^{1}$ Dipartimento di Chimica, Biologia e Biotecnologie, University of Perugia, Via Elce di Sotto, Perugia, Italy \\ 2 Dipartimento di Scienze Agrarie, Alimentari e Ambientali, University of Perugia, Borgo XX Giugno, Perugia, Italy
}

\begin{abstract}
The red swamp crayfish Procambarus clarkii is the most cosmopolitan invasive freshwater crayfish species in the world. High tolerance to a wide range of environmental conditions, among which its great ability to survive drought conditions, and the economic importance are the main factors of its spreading success.

The present study tests for the first time the survival of this species to different relative humidity (RH) conditions (plastic boxes with humidity controlling salt solutions at 30\%, 50\%, 70\%, 100\% RH) and its ability to orient in humidity gradients (dual-choice chambers $50-78 \% \mathrm{RH}, 60-75 \% \mathrm{RH}$ ). $P$. clarkii shows a great ability to survive out of water, positively related to the RH conditions, surviving more than 2 days at very low humidity $(30 \% \mathrm{RH})$ and more than 1 month at $100 \% \mathrm{RH}$. In addition the crayfish showed a positive hygrotaxis spending most of their time in the area of the choice chambers with a higher RH.

The results of the present investigation are particularly relevant considering that one of the major challenges to predict and control biological invasion lies in understanding which biological and ecological features might favor the colonization of alien invasive species in new areas.
\end{abstract}

Keywords: Behavior / Crustacea / freshwater alien species / desiccation / hygroreceptors

Résumé - Résistance à la déshydratation et hygrotaxie positive chez l'écrevisse de Louisiane envahissante Procambarus clarkii. L'écrevisse de Louisiane Procambarus clarkii est l'espèce d'écrevisse d'eau douce la plus cosmopolite au monde. Sa grande tolérance à un large éventail de conditions environnementales, parmi lesquelles sa grande capacité à survivre aux conditions de sécheresse, et son importance économique sont les principaux facteurs de son succès de propagation.

La présente étude teste pour la première fois la survie de cette espèce à différentes conditions d'humidité relative $(\mathrm{RH})$ (boîtes en plastique avec des solutions salines contrôlant l'humidité à 30\%, 50\%, 70\%, 100\% $\mathrm{RH}$ ) et sa capacité à s'orienter dans des gradients d'humidité (chambres à double choix 50-78\% RH, 60-75\% $\mathrm{RH})$. P. clarkii montre une grande capacité à survivre hors de l'eau, positivement liée aux conditions d'humidité relative, survivant plus de deux jours à très faible humidité (30\% d'humidité relative) et plus d'un mois à $100 \%$ d'humidité relative. En outre, les écrevisses ont montré une hygrotaxie positive en passant la plupart de leur temps dans la zone des chambres de choix avec une HR plus élevée.

Les résultats de la présente étude sont particulièrement pertinents étant donné que l'un des principaux défis à relever pour prédire et contrôler l'invasion biologique réside dans la compréhension des caractéristiques biologiques et écologiques susceptibles de favoriser la colonisation d'espèces exotiques envahissantes dans de nouvelles zones.

Mots-clés : Comportement / Crustacé / espèce exotique d'eau douce / dessiccation / hygro-récepteurs

\footnotetext{
*Corresponding author: antonia.elia@unipg.it
} 


\section{Introduction}

Alien species introduction is threatening biodiversity in various ways: genetic variation reduction and erosion of gene pools through the extinction of endemic species, and modification of habitat and ecosystem functioning (see review in Vilà et al., 2009). The North American crayfish Procambarus clarkii (Girard, 1852) (Decapoda, Cambaridae), also known as red swamp crayfish or Louisiana crayfish (see review in Loureiro et al., 2015), is native to northeastern Mexico and the southern USA and has been introduced all over the world except Antarctica and Oceania. This cosmopolitan freshwater crayfish (Hobbs, 1988; Gutiérrez-Yurrita et al., 1999; Lindqvist and Huner, 1999; Gherardi, 2006; Chucholl, 2011), is the most widely introduced freshwater crayfish species in the world. The main purpose of the introduction in Europe was initially its expected commercial exploitation in professional fisheries and freshwater aquaculture (SoutyGrosset et al., 2006). In invaded areas $P$. clarkii is responsible for pronounced environmental modifications causing severe damages in agricultural ponds and natural systems, like bank collapse (Correia and Ferreira, 1995) and negative ecological and economic consequences, such as the decline of native counterparts (Lodge et al., 2000; see review in Souty-Grosset et al., 2016). Furthermore, $P$. clarkii is a potential carrier of the crayfish plague (Aphanomyces astaci), lethal for the indigenous crayfish species and an importer of pathogenic microfungal taxa such as Phoma glomerata (Coelomycetes), potentially harmful to human health, flora and fauna (Dörr et al., 2011; 2012a and b). The possibility of spreading diseases by this species is an additional negative element linked to its presence on the territory.

Its great ability to colonize a wide range of environments is due to its peculiar behavioral and biological characteristics among which its aggressiveness inducing competitive displacement of native species (Dick et al., 1995; Gamradt et al., 1997; Usio et al., 2001). Moreover, its parental care improves reproductive fitness increasing offspring survival (Marchetti et al., 2004). Locomotion and dispersal ability increase rates of spread and spatial patterns of invasion (Johnson and Carlton, 1996; Lewis, 1998), while burrowing behavior helps coping with environmental stress factors (Gherardi, 2001). Definitely, $P$. clarkii is an efficient digger using burrows as refuge to protect from predators, to nest and protect offspring, and to deal with various environmental stresses like high temperatures and dehydration (Huner and Barr, 1991; Barbaresi and Gherardi, 2006; Carreira et al., 2017). The great ability of $P$. clarkii to withstand dehydration by dwelling in the hyporheic zone through vertical burrowing has been highlighted in a laboratory investigation simulating a period of 1-week drought at a relative humidity (RH) of $99 \%$ (Kouba et al., 2016). A previous laboratory investigation on the dehydration survival capacities of the same species, performed only at $30 \%$ $\mathrm{RH}$, reported that the red swamp crayfish began to die after $6 \mathrm{~h}$ of desiccation (with a $\mathrm{LT}_{50}$ of $11.9 \mathrm{~h}$ and $\mathrm{a} \mathrm{LT}_{90}$ of $17.6 \mathrm{~h}$ ) (Banha and Anastácio, 2014).

This is the first detailed study performed under controlled conditions showing the resistance to dehydration and the positive hygrotaxis behaviour in the invasive red swamp crayfish. The investigation was achieved testing survival of adult males to different $\mathrm{RH}$ values obtained with humidity controlling salt solutions $(30 \%, 50 \%, 70 \%, 100 \% \mathrm{RH})$, and their ability to orient inside humidity gradients $(50-78 \% \mathrm{RH}$, $60-75 \% \mathrm{RH})$.

\section{Material and methods}

\subsection{Experimental animals}

P. clarkii was collected in Lake Trasimeno (Umbria, Central Italy) from November 2016 to July 2017. The lake is an ideal habitat for this species and has been colonized successfully since 1999 (Dörr et al., 2001; Dörr and Scalici, 2013). After a rapid expansion, nowadays its hale population is well established and economically important for the local fish market and even for recreational activities (Dörr et al., 2006). To avoid any bias in the experiment, we selected intermoult and intact (integral walking legs, chelae, antennae and antennules) adult males (sexually active showing distinct grasping hooks on the ischia of the 3rd and 4th pairs of pereopods). Specimens wet weight ranged between 17.2 and $49.4 \mathrm{~g}$ with a carapace length between 39.60 and $55.75 \mathrm{~mm}$. Crayfish were acclimatized for at least 2 weeks in glass aquaria $(70 \mathrm{~cm} \times 30 \mathrm{~cm} \times 40 \mathrm{~cm})$ in laboratory. Twenty crayfish were collocated in each aquarium supplied with oxygenated tap water (previously exposed to air to remove chlorine), and fed with commercial aquaculture pellets ad libitum. Metal net was added to provide shelters. No special authorisation was required for collecting specimens in field and for laboratory activities.

\subsection{Resistance to dehydration}

Crayfish survival out of water was analysed in various conditions of RH, obtained by using aqueous solutions of $\mathrm{NaOH}$ at different concentration values (Madge, 1961). The experiments were carried out in square polypropylene plastic containers $(18 \mathrm{~cm} \times 18 \mathrm{~cm} \times 11 \mathrm{~cm})$ separated into a lower and an upper compartment by a median horizontal diaphragm of a plastic gauze ( $2 \mathrm{~mm}$ mesh). Humidity controlling substances were placed in the lower compartment of each container. A single crayfish was removed from water and placed on the gauze in the upper compartment of each cage, free to walk in the square arena without direct contact with the solution. Total wet weight and carapace length of each crayfish were recorded. Each container was covered with a tight-fitting lid.

Crayfish survival was tested at $30 \%, 50 \%, 70 \%$ and $100 \%$ RH. Fifteen specimens for each RH value were tested. Health condition of crayfish inside each box, as dead or alive (life criteria: locomotion and/or active motion of appendages when touched with a sterile glass stick), was checked once a day in the afternoon. The containers were opened at each observation time to remove dead specimens and to ensure oxygen replacement. Survival data were censored after 30 days of follow up. Before and at the end of the experiment, temperature and $\mathrm{RH}$ inside one container for each condition were monitored for $24 \mathrm{~h}$ using a thermo-hygrometer (HOBO H08-004-02 Onset Computer Corporation RH range 0-95\% accuracy $\pm 5 \%$, temperature range $-20{ }^{\circ} \mathrm{C} /+70{ }^{\circ} \mathrm{C}$ ). Fifteen crayfish were kept individually in polypropylene containers 
$(18 \mathrm{~cm} \times 18 \mathrm{~cm} \times 11 \mathrm{~cm})$ filled with aged tap water as control. Control water was oxygenated daily. During the acclimation period of at least 2 weeks $P$. clarkii was fed ad libitum. In consideration that this species is known to be able to survive for relatively long dry periods without food, and that the presence of diet could create bias in our experimental conditions crayfish were not fed during the trial.

Bioassays were performed in a thermostatically controlled experimental room at $25^{\circ} \mathrm{C}$ and $50-60 \% \mathrm{RH}$.

\subsection{Ability to orient in a humidity gradient}

The crayfish response in different humidity gradients was tested in dual-choice chambers similar to those described by Arbogast and Carthon (1971). Each chamber consisted of two parts made using boxes of clear polypropylene plastic $(23 \mathrm{~cm} \times 30 \mathrm{~cm} \times 6 \mathrm{~cm})$. The lower part was a box divided by a median wall into two compartments. The upper part was a walking arena consisting of an identical box with a floor of plastic gauze (1-mm mesh), and covered with a glass plate. Solutions with different concentrations of $\mathrm{NaOH}$ (Madge, 1961) filled the two compartments of the lower box to provide contrasting humidity on the two sides of the walking arena placed over it. The fine plastic mesh on the arena floor allowed diffusion of water vapour preventing contact of the crayfish with the caustic solutions. Temperature and $\mathrm{RH}$ inside each side of the arena were monitored using a thermo-hygrometer.

Two bioassays were performed in two different gradients. In the first set of chambers the solutions provided a diffusion gradient from 50 to $78 \% \mathrm{RH}$ on the two sides of the walking arena; in the second set of chambers the gradient was from 60 to $75 \% \mathrm{RH}$. To allow for sufficient stabilization, $12 \mathrm{~h}$ before the experiments, the two compartments of the lower box of each chamber were filled with the solutions and the arena was mounted and closed with the glass plate. In each replicate, one crayfish was removed from water and maintained half an hour in an empty polypropylene box to dry out. Later, it was placed in the centre of the walking arena and covered with the glass plate. After $5 \mathrm{~min}$ of acclimation, the movements of the specimen (walking and staying in the two sides of the arena or on the separation line) were directly observed from a distance of $3 \mathrm{~m}$ and recorded for $1.5 \mathrm{~h}$. At the end of each bioassay the net of the walking arena was removed and cleaned with water and odour-free detergent; the whole walking arena was washed with the same detergent every 2-3 bioassays.

The possible presence of bias was evaluated by running controls consisting of chambers with the two compartments in the lower box filled with distilled water, to obtain a walking arena with around $100 \%$ RH everywhere. For the bioassays we used intact crayfish and ablated crayfish, whose antennae and antennulae were gently removed by dissection scissors 1 day before the bioassays. Ablated crayfish were tested only for the higher humidity gradient in consideration that our aim was simply to understand if they were able or unable to perceive humidity in relation to the possible presence of hygroreceptors on antennae and antennulae.

We removed antennae and antennulae because both are important sensory organs in Crustacea (antennae mainly for mechanoreception and antennulae mainly for chemoreception, Koch et al., 2006; Derby and Sorensen, 2008) and no data are available on the presence or location of hygroreceptors in crayfish. Intact crayfish were tested in both humidity gradients.

Sixteen replicates were performed for each gradient and 18 replicates for the controls with intact crayfish. Twelve replicates were performed both for the gradient from 50 to $78 \% \mathrm{RH}$ and for the controls with ablated crayfish. One crayfish was tested in each replicate. All tests were conducted between 09.00 and $15.00 \mathrm{~h}$ (CEST). The bioassay room was maintained at $25^{\circ} \mathrm{C}$ and $50 \% \mathrm{RH}$.

\subsection{Statistical analysis}

The survival analysis for multiple samples, using an extension of Peto and Peto's generalized Wilcoxon test, was applied to compare crayfish survival at the different experimental conditions. Survival functions for the different groups were plotted using the cumulative proportion of surviving (Kaplan-Meier curves) (Statistica 6.0, Statsoft Inc., 2001). The crayfish mean longevity at the various conditions of humidity and their weight was analysed by one-way ANOVA (Statistica 6.0, Statsoft Inc., 2001). Each crayfish was considered as a replicate.

The percentage of time (residence time) spent in each of the two sides of the arena was compared using the $t$-test for dependent samples (Statistica 6.0, Statsoft Inc., 2001). Data were reported and analysed as percentage of time spent on the total time $(90 \mathrm{~min})$ or on the first minute of the experiment. The percentage of time (residence time) spent by crayfish on the separation line (no choice) was not considered in the analysis and was not shown in figures because very low. $t$-Test for independent samples was used to compare the residence time and the activity (defined as the number of transitions between the two sides of the walking arena) of intact and ablated crayfish in the control situation both for the total duration and for the first minute of the experiment. One-way ANOVA was used to compare the residence time and the activity in the different $\mathrm{RH}$ gradients both for the total duration and for the first minute of the experiment. All internal comparisons were submitted to unequal N HSD Tukey test (Statistica 6.0, Statsoft Inc., 2001). Before the analysis, Box-Cox transformation was used to reduce data heteroscedasticity (Sokal and Rohlf, 1998).

\section{Results}

\subsection{Resistance to dehydration}

Crayfish survival at the different humidity and in the control water was significantly different $\left(\chi^{2}=66.55, d f=4\right.$, $P<0.001$ ). The longevity curves (proportion surviving plotted against time) appeared similar in shape at 30\%, 50\% and $70 \%$ $\mathrm{RH}$, with a great slope and the death of all crayfish nearly simultaneous at each RH level. Differently, curves at $100 \% \mathrm{RH}$ and the control showed a flat shape and the surviving of the most part of specimens for all the experimental period (30 days); (Fig. 1). In particular, at $100 \%$ RH, $73 \%$ of the tested crayfish survived more than 30 days, similarly to the control (water), where $80 \%$ of crayfish survived more than 30 days. At $30 \%, 50 \%$ and $70 \% \mathrm{RH}, 100 \%$ of tested individuals died between 2 and 7 days (Fig. 1). The mean longevity recorded in the different tested conditions was statistically different 


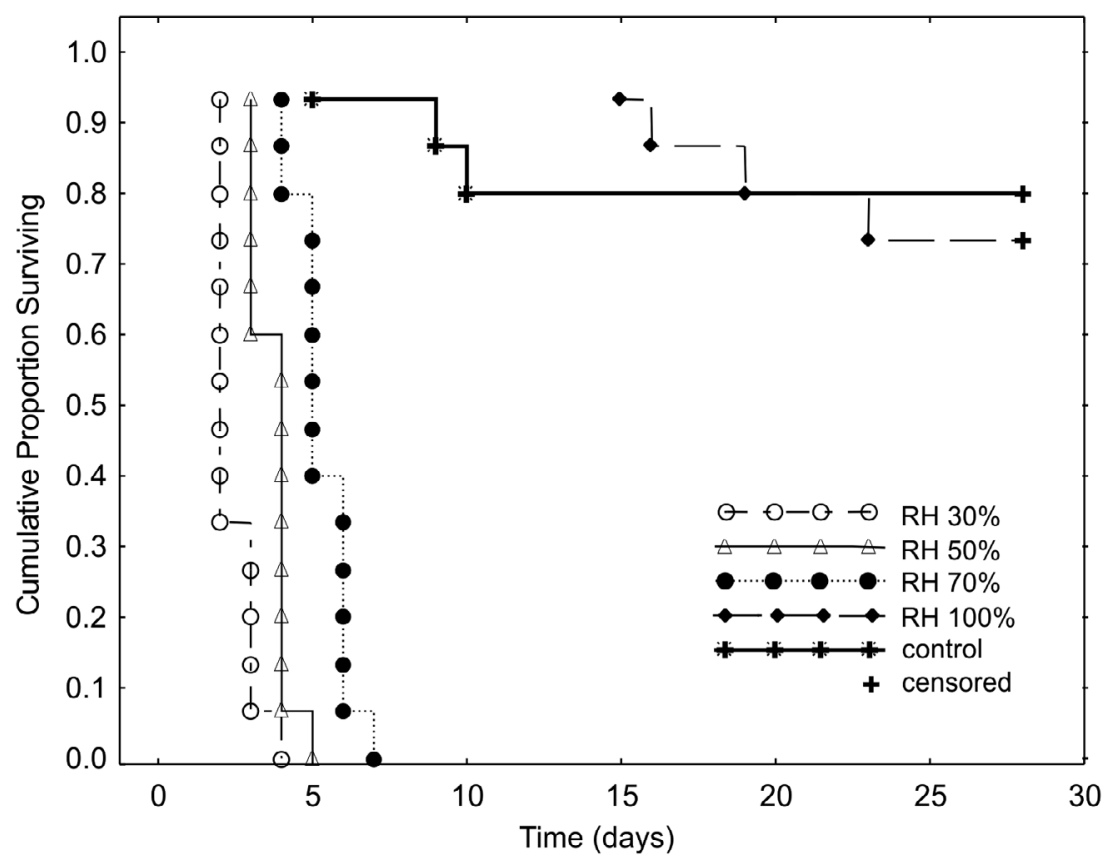

Fig. 1. Cumulative proportion of $P$. clarkii surviving at different humidity $(30-50-70-100 \% \mathrm{RH})$ and for control (not fed) at $25^{\circ} \mathrm{C}$. Note that at $100 \%$ relative humidity $(\mathrm{RH})$ most of the crayfish $(73 \%)$ survived longer than the experimental time ( 30 days) and no crayfish died before $48 \mathrm{~h}$ for any condition. Data were censored for 30 days.

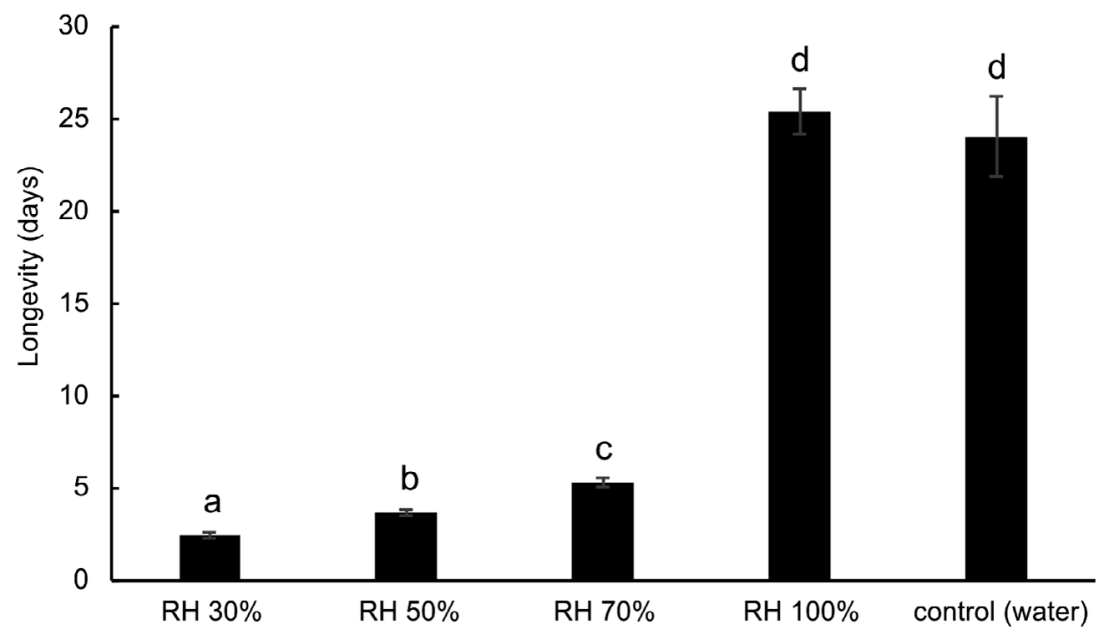

Fig. 2. Mean time of crayfish longevity at different humidity (30-50-70-100\% RH) and for control (not fed) at $25^{\circ} \mathrm{C}$. Bars indicate mean $\pm \mathrm{SE}$. Data with different letters are significantly different at $P<0.05$ (one-way ANOVA, unequal N HSD Tukey test).

$(F=176.68 ; d f=4,70 ; P<0.001)$ (Fig. 2). Indeed, the longevity of crayfish tested at $100 \% \mathrm{RH}$ and in the control was not different and significantly higher than that recorded at lower RH, where it increased significantly together with the $\mathrm{RH}$ values (Fig. 2). Weight $(29.46 \pm 0.89$, mean \pm SE) of crayfish tested in various conditions of humidity was not statistically different $(F=0.44 ; d f=4,70 ; P=0.777)$.

\subsection{Ability to orient in a humidity gradient}

Considering the total period of the bioassays in the dualchoice chambers, intact crayfish spent most of their time in the side of the arena with a higher $\mathrm{RH}$, both in $50-78 \% \mathrm{RH}$ $(t=166.51 ; d f=15 ; P<0.001)$ and in $60-75 \% \mathrm{RH}$ gradient $(t=7.47 ; d f=15 ; P<0.001)$. Also for ablated crayfish, the residence time was significantly higher inside of the arena with higher $\mathrm{RH}$ in the tested gradient $(50-78 \% \mathrm{RH})(t=8.07$; $d f=11 ; P<0.001)$ (Fig. 3). Intact crayfish spent more time in the moister area of the two gradients, also considering only the first minute of the bioassay $(50-78 \% \mathrm{RH}$ gradient: $t=6.44$; $d f=15 ; P<0.001 .60-75 \%$ RH gradient: $t=-4.39 ; d f=15$; $P=0.0005)$, while ablated crayfish did not show any preference during the first minute of the test $(t=1.98$; $d f=11 ; P=0.073$ ) (Fig. 3). For control both intact and ablated specimens showed no significant difference between time spent in each of the two sides of the arena considering the 


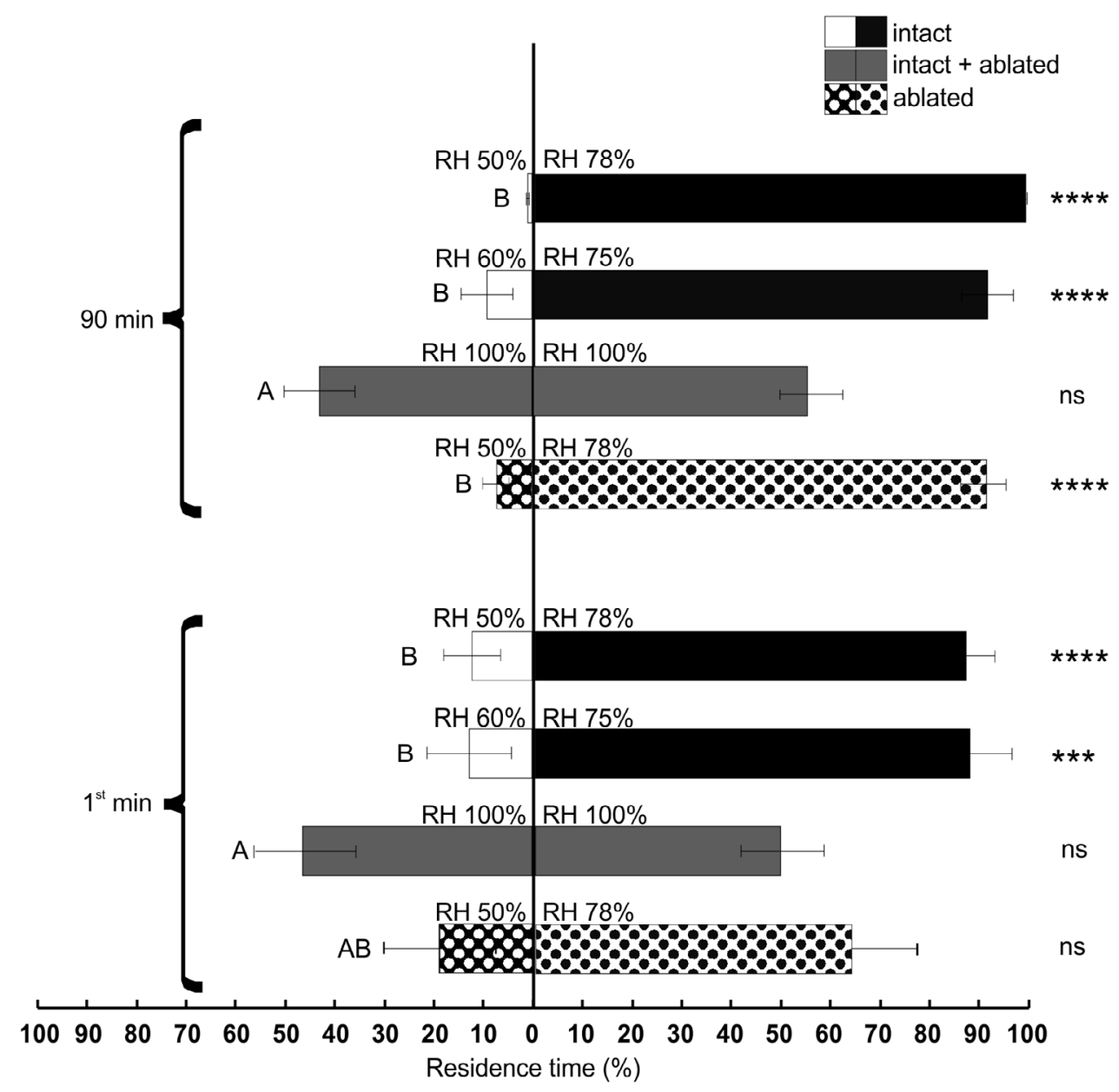

Fig. 3. Time percentage (mean \pm SE) spent by intact and ablated crayfish in each of the two sides of the walking arena in $50-78 \%$ RH chambers ( $n=16$ for the intact crayfish and $n=12$ for the ablated ones), $60-75 \%$ RH chambers ( $n=16$, only intact crayfish), and in the control ( $n=18$ for intact crayfish and $n=12$ for ablated ones). For controls, no significant differences were recorded between behaviour of ablated and intact crayfish so they were pooled together. Data from the whole experimental time, $90 \mathrm{~min}$, and from the first minute of the test are analysed independently. ${ }^{* * * *} P<0.0001,{ }^{* * *} 0.0001<P<0.001$; ns, not significant ( $t$-tests for dependent samples). Data with different letters are significantly different at $P<0.05$ (one-way ANOVA, unequal N HSD Tukey test).

whole experimental time (intact: $t=-0.74 ; d f=17 ; P=0.468$, ablated: $t=-0.59 ; d f=11 ; P=0.568)$ and the first minute (intact: $t=-0.01 ; d f=17 ; \quad P=0.990$, ablated: $t=-0.29$; $d f=11 ; P=0.777)$. In consideration that in controls no significant differences in the response of ablated crayfish and intact ones were registered, both for the whole experimental time $(t=-0.53 ; d f=29 ; P=0.599)$ and for the first minute $(t=-0.53 ; d f=29 ; P=0.601)$, we pooled them together in the comparison among the residence times in the arenas with different $\mathrm{RH}$ values (Fig. 3).

When comparing the residence time in the side of the arena with lower RH of intact and ablated crayfish in the tested gradients, considering the whole experimental time, it was significantly lower compared to the control in all the tested gradients, both for intact and ablated crayfish, without any difference among the different conditions $(F=23.25 ; d f=3$, $70 ; P<0.001)$ (Fig. 3). In the first minute, the residence time in the side of the arena with lower RH in the tested gradients was lower compared to the control for intact crayfish but intermediate for ablated ones $(F=5.05 ; \quad d f=3, \quad 70$;
$P=0.003)$ (Fig. 3). Percentage of time spent by crayfish on the separation line (no choice) was almost negligible (maximum 3\%), except in the case of the first minute of experiment with ablated crayfish $(16.7 \% \pm 11.2 \%)$.

Crayfish activity was significantly different in the various tests $(F=7.69 ; d f=3,70 ; P<0.001)$ (Fig. 4$)$. In consideration that in the controls there was no significant difference in the activity of ablated crayfish and intact ones $(t=1.99 ; d f=28$; $P=0.065)$, we pooled them together. Intact crayfish activity tested in the two RH gradients was lower than activity in the control. Ablated crayfish activity was intermediate between the activity of intact specimens in the two RH gradients and that of the control. Moreover, there was no difference between the activity of the intact crayfish in the two RH gradients (Fig. 4).

\section{Discussion and conclusions}

Our data show a great ability of the crayfish $P$. clarkii to survive out of water, strongly related to the RH conditions. Indeed, even at a very low level of humidity such as $30 \% \mathrm{RH}$ 


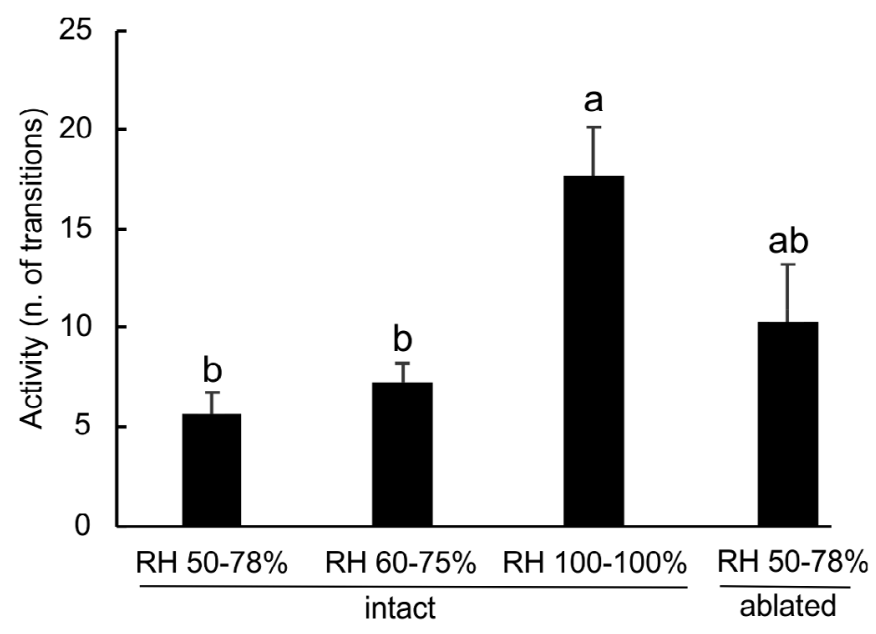

Fig. 4. Crayfish activity, defined as the number of transitions between the two sides of the walking arena, of ablated and intact crayfish in the tested types of dual-choice chambers $(50-78 \% \mathrm{RH}$ and $60-75 \% \mathrm{RH}$ gradients) and in the control $(100-100 \% \mathrm{RH})$. For controls, no significant differences were recorded between behaviour of ablated and intact crayfish so they were pooled together. Data with different letters are significantly different at $P<0.05$ (one-way ANOVA, unequal N HSD Tukey test).

(which is not frequent in the areas surrounding inland waters), none of our specimens died before 48 hours and more than $70 \%$ of the crayfish maintained at $100 \%$ RH survived more than 30 days, without any difference with the crayfish kept in water (controls). These data are in agreement with those reported by Kouba et al. (2016) in a laboratory investigation simulating a period of 1-week drought at a $99 \% \mathrm{RH}$, but are highly different from those reported in another laboratory investigation where at 30\% RH P. clarkii began to die after $6 \mathrm{~h}$ and did not survive 1 day of desiccation (Banha and Anastácio, 2014). The differences concerning our results, when compared to the Banha and Anastácio studies, are likely due to different experimental conditions.

Other investigations on the ability to survive drought conditions in aquatic arthropods, which can face dehydration, such as dragonfly larvae living in small astatic pools have been performed in the past using the same method (Piersanti et al., 2007; Rebora et al., 2007). Among crustaceans a similar investigation has been carried out only on three species of Talitridae, typically living in the intertidal zone, showing a survival time ranging between one and $48 \mathrm{~h}$, and strongly dependent on the RH values (Williamson, 1951). The resistance to dehydration shown by $P$. clarkii in our investigation is similar to that reported for some terrestrial crabs (about 3-4 days an RH of $78-90 \%$ RH values) (Burggren and McMahon, 1981) even if, as far as we know, no detailed investigation testing the survival under different controlled RH conditions has been performed in Decapoda. In relation with the high resistance shown by $P$. clarkii, it is important to remember that many crayfish species developed strategies to become the dominant decapods not only in freshwater but also in the surrounding terrestrial habitats (Reynolds et al., 2013). P. clarkii is considered a "tertiary burrower" (Hobbs, 1981), spending most of its life in open waters and only retreating in burrows to avoid predators and dehydration or when breeding (Gherardi, 2001). On the other hand, a terrestrial behavior was reported by Huner (2002), Chucholl (2011) and Abdel-Kader (2016) who observed $P$. clarkii migrating overland to explore new habitats in response to poor water quality (McCarthy et al., 2014) or for dispersal among waterways (Morgan, 1991; Furse et al., 2004; Herrmann et al., 2018).

The colonization of terrestrial habitats by some decapods has required considerable morphological, physiological and behavioral modification, mainly concerning ion regulation and gas exchange. These processes have been investigated extensively in terrestrial crabs (Burggren and McMahon, 1981). Crayfish can breathe out of water since their gills are protected by the carapace and do not collapse in air for some time (Reynolds et al., 2013). Most crayfish can switch from water to air as an oxygen source (McMahon, 2002) and may leave water bodies when their oxygen levels have become depleted. The shape of our longevity curves, with a great slope and the death of all the crayfish nearly simultaneous at $30 \%$, $50 \%$ and $70 \% \mathrm{RH}$ and with a flat shape at $100 \% \mathrm{RH}$, could be in agreement with a death due to gill dehydration, but further investigations are necessary to test this hypothesis.

Our bioassays in the dual-choice chambers showed that crayfish spent most of their time in the side of the arena with a higher RH. A recent study on environmental cues driving overland dispersal by $P$. clarkii reports that movement direction and dispersal are influenced by gradients of temperature and elevation while, unexpectedly, they are not related with RH values (Marques et al., 2015). These variances, if compared to our results, can be due to lower humidity values $(32-55 \%)$ as hypothesized by the same authors or may depend on differences in the experimental setup. In fact our crayfish were tested in small $(30 \mathrm{~cm} \times 23 \mathrm{~cm})$ dual choice chambers where RH was constant and controlled by saline solutions, while Marques et al. (2015) used $200 \mathrm{~cm}$ metal gutters humidity stimuli produced by nebulizers collocated only at their ends and not monitored in the centre. The positive hygrotaxis shown by $P$. clarkii in air is surely relevant to orientate its burrowing behavior. In a behavioural study investigating the ability of this species to learn the position of a wet burrow hidden to its sight and move towards it. Barbaresi and Gherardi (2006) hypothesized the use of a combination of tactile and visual information jointly with the potential use of humidity cues, but the authors highlight that the study was not designed to investigate the sensory channels used by $P$. clarkii to orient. The ability to orient in humidity gradients at a microclimatic scale is a crucial aspect in arthropod habitat selection in order to regulate body water loss, especially in terrestrial species such as insects and arachnids, where thermo-hygroreceptors have been extensively investigated, and are typically constituted of two antagonistic hygroreceptor neurons (moist and dry) and one cold neuron forming a triad in a single antennal sensillum (Tichy and Loftus, 1996; Steinbrecht, 1998; Rebora et al., 2007; Piersanti et al., 2011). Among Crustacea, putative hygroreceptors have been reported only in the terrestrial isopod Porcellio scaber showing numerous cuticular tricorn sensilla on the surface of the whole body with a morphology resembling insect hygroreceptors (Ziegler and Altner, 1995). In any case, these authors suggest that structural criteria for thermo-hygrosensitivity used in insects cannot simply be applied to crustaceans. 
Recent investigations on humidity sensation in Coenorhabditis elegans (Russell et al., 2014) and humans (Filingeri et al., 2014) confirmed that in some animals humidity may be perceived as the synthesis of mechanical and thermal signals without a specific sensory organ, thus revealing a remarkable similarity in the hygrosensation transduction mechanism used by hygroreceptors provided (e.g. insects) and hygroreceptors lacking (e.g. roundworms and humans) species, all able to detect humidity (Filingeri, 2015). Our data on crayfish with ablated antennae show that they are still able to orient and select for a high $\mathrm{RH}$ value, but this hygrotaxis needs more than one minute to be expressed, while one minute is enough for the positive hygrotaxix of intact specimens. In addition, these crayfish showed a level of activity in the bioassays similar to that of control. We can exclude that the stress due to the amputation affects these results, because no difference in activity and hygrotaxis occurred between the control bioassays of ablated and intact crayfish. These results suggest that $P$. clarkii could have specific hygroreceptors on the antennae and somewhere else on the body surface, but we cannot exclude a different pathway for hygrosensitivity in these arthropods as suggested for other animals (Filingeri, 2015). Further morphological and physiological investigations could clarify this interesting aspect in Crustacea.

In conclusion, the present study represents the first detailed description of the ability of the red swamp crayfish to survive at different degrees of dehydration, and to select moist environments following humidity cues, which allow this species to survive periods of drought by constructing burrows, and also disperse migrating overland. Positive hygrotaxis and the aptitude to withstand dehydration are relevant to confirm the notable ecological plasticity of the red swamp crayfish, and this knowledge can be a useful tool serving to control and to contain this resilient invasive alien crayfish.

Acknowledgements. We are grateful to A. Sotgiu for crayfish care in laboratory and to S. Andreoli, T. Arcangeli, S. Biondolillo, F. De Matteis and L. Severini for helping in data collection. We also thank Orietta Morettini and the professional fishermen of the "Cooperativa Alba" of Lake Trasimeno for supplying crayfish. The Authors are indebted to the anonymous reviewers for insightful comments and suggestions. Funding was provided by the University of Perugia, Department of Chemistry, Biology and Biotechnology, Ricerca di Base 2014 fund.

\section{References}

Abdel-Kader SM. 2016. Some ecological and toxicological studies on crayfish, Procambarus clarkii at Sharkia governorate, Egypt. $J$ Basic Appl Zool 74: 62-67.

Arbogast RT, Carthon M. 1971. Humidity response of the larvae of Oryzaephilus surinamensis (Coleoptera: Curcujidae). Ann Entomol Soc Am 64: 90-93.

Banha F, Anastácio P. 2014. Desiccation survival capacities of two invasive crayfish species. Knowl Manag Aquat Ecosyst 413: 1-5.

Barbaresi S, Gherardi F. 2006. Experimental evidence for homing in the red swamp crayfish, Procambarus clarkii. Bull Fr Pêche Piscic 380-381: 1145-1154

Burggren WW, McMahon BR. 1981. Hemolymph oxygen transport, acid-base status, and hydromineral regulation during dehydration in three terrestrial crabs, Cardisoma, Birgus, and Coenobita. J Exp Zool 218: 53-64.

Carreira BM, Segurado P, Laurila A, Rebelo R. 2017. Can heat waves change the trophic role of the world's most invasive crayfish? Diet shifts in Procambarus clarkii. PLoS One| https://doi.org/10.1371/ journal.pone. 0183108 .

Chucholl C. 2011. Population ecology of an alien "warm water" crayfish (Procambarus clarkii) in a new cold habitat. Knowl Manag Aquatic Ecosyst 401: 1-21.

Correia AM, Ferreira O. 1995. Burrowing behavior of the introduced red swamp crayfish Procambarus clarkii (Decapoda: Cambaridae) in Portugal. J Crustac Biol 15: 248-257.

Derby CD, Sorensen PW. 2008. Neural processing, perception, and behavioural responses to natural chemical stimuli by fish and crustaceans. J Chem Ecol 34: 898-914.

Dick JTA, Elwood RW, Montgomery WI. 1995. The behavioral basis of a species replacement: differential aggression and predation between the introduced Gammarus pulex and the native $G$. duebenicelticus (Amphipoda). Behav Ecol Sociobiol 37: 393-398.

Dörr AJM, Pedicillo G, Lorenzoni M. 2001. Prima segnalazione in Umbria di Procambarus clarkii (Girard), Orconectes limosus (Rafinesque) e Astacus leptodactylus Eschscholtz, (Crustacea Decapoda). Riv Idrobiol 40: 2-3.

Dörr AJM, La Porta G, Pedicillo G, Lorenzoni M. 2006. Biology of Procambarus clarkii (Girard, 1852) in Lake Trasimeno. Bull Fr Pêche Piscic 380-381: 1155-1168.

Dörr AJM, Rodolfi M, Scalici M, Elia AC, Garzoli L, Picco AM. 2011. Phoma glomerata, a potential new threat to Italian inland waters. J Nat Conserv 19: 370-373.

Dörr AJM, Elia AC, Rodolfi M, et al. 2012a. A model of cooccurrence: segregation and aggregation patterns in the mycoflora of the crayfish Procambarus clarkii in Lake Trasimeno (central Italy). J Limnol 71: 135-143.

Dörr AJM, Rodolfi M, Elia AC, Scalici M, Garzoli L, Picco AM. 2012b. Mycoflora on the cuticle of the invasive crayfish Procambarus clarkii. Fundam Appl Limnol 180/1: 77-84

Dörr AJM, Scalici M. 2013. Revisiting reproduction and population structure and dynamics of Procambarus clarkii eight years after its introduction into Lake Trasimeno (Central Italy). Knowl Manag Aquat Ecosyst 408: 10-16.

Filingeri D. 2015. Humidity sensation, cockroaches, worms, and humans: are common sensory mechanisms for hygrosensation shared across species? J Neurophysiol 114: 763-767.

Filingeri D, Redortier B, Hodder S, Havenith G. 2014. Thermal and tactile interactions in the perception of local skin wetness at rest and during exercise in thermo-neutral and warm environments. Neuroscience 258: 121-130.

Furse JM, Wild CH, Villamar NN. 2004. In-stream and terrestrial movements of Euastacus sulcatus in the Gold Coast hinterland: developing and testing a method of accessing freshwater crayfish movements. Freshw Crayfish 14: 213-220.

Gamradt SC, Katz LB, Anzalone CB. 1997. Aggression by non-native crayfish deters breeding in California newts. Conserv Biol 11: 793796.

Gherardi F. Behaviour. In: Holdich DM, ed. Biology of freshwater crayfish. Oxford: Blackwell Science, 2001, pp. 258-290.

Gherardi F. 2006. Crayfish invading Europe: the case study of Procambarus clarkii. Mar Freshw Behav Physiol 39: 175-191.

Gutiérrez-Yurrita PJ, Martínez JM, Bravo-Utrera MÁ, Montes C, Ilhéu M, Bernardo JM. The status of crayfish populations in Spain and Portugal. In: Gherardi F, Holdich DM, ed. Crayfish in Europe as alien species: how to make the best of a bad situation? Rotterdam: A.A. Balkema, 1999, pp. 161-192. 
Herrmann A, Schnabler A, Martens A. 2018. Phenology of overland dispersal in the invasive crayfish Faxonius immunis (Hagen) at the Upper Rhine River area. Knowl Manag Aquat Ecosyst 419: 30.

Hobbs HH. 1981. The crayfishes of Georgia. Smithson Contrib Zool 318: $1-549$.

Hobbs HH. Crayfish distribution, adaptive radiation, and evolution. In: Holdich DM, Lowery RS, ed. Freshwater crayfish: biology, management and exploitation. London: Croom Helm, 1988, pp. $52-82$.

Huner JV. Procambarus. In: Holdich DM, ed. Biology of freshwater crayfish. Oxford: Blackwell Science, 2002, pp. 541-584.

Huner JV, Barr JE. 1991. Red swamp crayfish: biology and exploitation. The Louisiana Sea Grant College Program, Center for Wetland Resources. Baton Rouge, LA: Louisiana State University.

Johnson LE, Carlton JT. 1996. Post-establishment spread in largescale invasions: dispersal mechanisms of the zebra mussel (Dreissena polymorpha). Ecology 77: 1686-1687.

Koch LM, Patullo BW, Macmillan DL. 2006. Exploring with damaged antennae: do crayfish compensate for injuries? J Exp Biol 209: 3226-3233.

Kouba A, Tíkal J, Císař P, et al. 2016. The significance of droughts for hyporheic dwellers: evidence from freshwater crayfish. Sci Rep 6: 26569

Lewis MA. Variability, patchiness and jump dispersal in the spread of an invading population. In: Tilman D, Kareiva P, eds. Spatial ecology: the role of space in population dynamics and interspecific interactions. Princeton: Princeton University Press, 1998, pp. 46-69.

Lindqvist OV, Huner JV. Life history characteristics of crayfish: What makes some of them good colonizers? In: Gherardi F, Holdich DM, eds. Crayfish in Europe as alien species: how to make the best of a bad situation? Rotterdam: A.A. Balkema, 1999, pp. 23-30.

Lodge DM, Taylor CA, Holdich DM, Skurdal J. 2000. Nonindigenous crayfish threaten North American freshwater biodiversity: lessons from Europe. Fisheries 25: 7-19.

Loureiro TG, Anastácio PMSG, Araujo PB, Souty-Grosset C, Almerão MP. 2015. Red swamp crayfish: biology, ecology and invasion - an overview. Nauplius 23: 1-19.

Madge DS. 1961. The control of relative humidity with aqueous solutions of sodium hydroxide. Entomol Exp Appl 4: 143-147.

Marchetti MP, Moyle PB, Levine R. 2004. Invasive species profiling? Exploring the characteristics of non-native fishes across invasion stages in California. Freshw Biol 49: 646-661.

Marques M, Banha F, Àguas M, Anastácio P. 2015. Environmental cues during overland dispersal by three freshwater invaders: Eriocheir sinensis, Pacifastacus leniusculus, and Procambarus clarkii (Crustacea, Decapoda). Hydrobiologia 742: 81-93.

McCarthy B, Zukowski S, Whiterod N, Vilizzi L, Beesley L, King A. 2014. Hypoxic blackwater event severely impacts Murray crayfish (Euastacus armatus) populations in the Murray River, Australia. Austral Ecol 39: 491-500.
McMahon BR. Physiological adaptation to environment. In: Holdich DM, ed. Biology of freshwater crayfish. Oxford: Blackwell Science, 2002, pp. 327-376.

Morgan GJ. 1991. The spiny freshwater crayfish of Queensland. Qld Nat 31: 29-36.

Piersanti S, Rebora M, Salerno G, Gaino E. 2007. Behavioural strategies of the larval dragonfly Libellula depressa (Odonata: Libellulidae) in drying pools. Ethol Ecol Evol 19: 127-136.

Piersanti S, Rebora M, Almaas TJ, Salerno G, Gaino E. 2011. Electrophysiological identification of thermo- and hygro-sensitive receptor neurons on the antennae of the dragonfly Libellula depressa. J Insect Physiol 57: 1391-1398.

Rebora M, Piersanti S, Salerno G, Conti E, Gaino E. 2007. Water deprivation tolerance and humidity response in a larval dragonfly: a possible adaptation for survival in drying ponds. Physiol Entomol 32: $121-26$.

Reynolds DJ, Souty-Grosset C, Richardson AMM. 2013. Ecological role of crayfish in freshwater and terrestrial habitats. Freshw Crayfish 19: 197-2018.

Russell J, Vidal-Gadea AG, Makay A, Lanam C, Pierce-Shimomura JT. 2014. Humidity sensation requires both mechanosensory and thermosensory pathways in Caenorhabditis elegans. Proc Natl Acad Sci USA 111: 8269-8274.

Sokal RR, Rohlf FJ. 1998. Biometry. New York: Freeman WE.

Souty-Grosset C, Anastácio PM, Aquiloni L, Banha F, Choquer J, Chucholl C, Tricarico E. 2016. Impacts of the red swamp crayfish Procambarus clarkii on European aquatic ecosystems and human well-being. Limnologica 58: 78-93.

Souty-Grosset C, Holdich DM, Noel PY, Reynolds JD, Haffner P. 2006. Atlas of Crayfish in Europe. Publications Scientifiques du Muséum national d'Histoire naturelle. Paris: Patrimoines Naturels.

Statsoft Inc. 2001. Statistica (data analysis software system) version 6. Vigonza: StatSoft Italia S.R.L.

Steinbrecht RA. 1998. Bimodal thermo- and hygrosensitive sensilla. In: Harrison FW, Locke M, eds. Microscopic anatomy of invertebrates 11B. New York: Wiley-Liss, pp. 405-422.

Tichy H, Loftus R. 1996. Hygroreceptors in insects and a spider: humidity transduction models. Naturwissenschaften 83: 255-263.

Usio N, Konishi M, Nakano S. 2001. Species displacement between an introduced and a "vulnerable" crayfish: the role of aggressive interactions and shelter competition. Biol Invasions 3: 179-185.

Vilà M, Basnou C, Pysêk P, et al. 2009. How well do we understand the impacts of alien species on ecological services? A panEuropean cross-taxa assessment. Front Ecol Environ 8: 135-144.

Williamson DI. 1951. Studies in the biology of Talitridae (Crustacea, Amphipoda): effects of atmospheric humidity. J Mar Biol Assoc UK 30: 73-89.

Ziegler A, Altner H. 1995. Are the most numerous sensilla of terrestrial isopods hygroreceptors? Ultrastructure of the dorsal tricorn sensilla of Porcellio scaber. Cell Tissue Res 282: 135-145.

Cite this article as: Piersanti S, Pallottini M, Salerno G, Goretti E, Elia AC, Dörr AJM, Rebora M. 2018. Resistance to dehydration and positive hygrotaxis in the invasive red swamp crayfish Procambarus clarkii. Knowl. Manag. Aquat. Ecosyst., 419, 36. 